\title{
Kualitas Lulusan Program Studi Pendidikan Teknik Mesin Universitas Palangka Raya Dalam Dunia Usaha/Industri
}

\author{
Wiyogo $^{(1)^{*}}$, Ahmad Eko Suryanto ${ }^{(1)}$, Galfri Siswandi ${ }^{(1)}$, Supriyadi ${ }^{(1)}$, \\ Vincensius Golderiawan ${ }^{(1)}$ \\ ${ }^{(1)}$ Pendidikan Teknik Mesin, Fakultas Keguruan dan Ilmu Pendidikan \\ Universitas Palangka Raya \\ *Email Author: wiyogo@fkip.upr.ac.id
}

Diterima:12-11-2021; Diperbaiki:10-02-2022; Disetujui:07-03-2022

\begin{abstract}
ABSTRAK
Penelitian ini bertujuan mendeskripsikan penilaian pengguna alumni terhadap kompetensi lulusan, sehingga mengetahui atribut apa saja yang dianggap penting yang harus dimiliki lulusan Pendidikan Teknik Mesin Universitas Palangka Raya, selanjutnya mengetahui rekomendasi perbaikan seperti apa yang bisa diberikan kepada pihak penyellenggara pendidikan. Instrumen yang digunakan berupa kuesioner. Data dianalsisi secara deskriptif. Hasil penelitian didapatkan kesenjangan terbesar dari lima level keahlian adalah keahlian level of keyboard competency dengan jumlah persentase hanya $68 \%$ dengan nilai capaiannya hanya mencapai 17 dari nilai target 25 . Kesenjangan kedua pada level enterprise and entrepreneurial skills hanya mencapai persentase $78 \%$ dengan nilai capaiannya hanya 19.5 dari nilai target 25 . Terdapat tiga keahlian yang mendapatkan persentase nilai yang cukup baik seperti keahlian interpersonal Skill mencapai persetase ketercapaianya $89 \%$ atau dengan nilai capaiannya 35.5. dari nilai target 40 , pada level ini merupakan yang tertinggi. Level keahlian manajemen skill menempati urutan kedua, dengan persentase $87 \%$ dengan nilai capaiannya 39 dari nilai target sebesar 45, dan komunikasi skill menempati urutan ketiga yang terbaik capaiannya yaitu dengan persentase $83 \%$, memiliki nilai capaian 50 dari nilai target 60 .
\end{abstract}

\section{Kata kunci: Kompeten, Kompetensi, keahlian}

\section{PENDAHULUAN}

Dalam Undang - undang Nomor 20 tahun 2003, pendidikan kejuruan merupakan salah satu pendidikan dalam perguruan tinggi (PT) yang diberikan kebebasan secara akademik, hal tersebut terutama tertuang pada pasal 24 ayat 1 , yaitu sebagai berikut; "Dalam penyelenggaraan pendidikan dan pengembangan ilmu pengetahuan, pada perguruan tinggi berlaku kebebasan akademik dan kebebasan mimbar akademik serta otonomi keilmuan”. Kemudian pada Pasal 35 ayat (1) menyebutkan bahwa kompetensi lulusan merupakan kualifikasi kemampuan lulusan yang mencakup sikap, pengetahuan, dan keterampilan sesuai dengan standar nasional yang telah disepakati. Snedden dalam Margisson (2001, dikutip dalam Sudiyanto, 2015), menyatakan tujuan utama dari suatu penyelenggaran pendidikan kejuruan yaitu untuk memenuhi kebutuhan tenaga kerja dan untuk menyiapkan siswa dengan kemampuan khusus agar cepat terserap di industri. Kemudian menurut UNNESCO (2001), penyelenggaraan pendidikan 
kejuruan bukan hanya mempersiapkan keahlian dalam suatu jabatan, tetapi juga mempersiapkan lulusan dalam pengayaan keterampilan dan pengetahuan dalam keterampilan - keterampilan umum lainnya yang ada di masyarakat. Hal tersebut sejalan dengan dengan perlu suatu sumber daya manusia (SDM) yang sesuai dengan kebutuhan masyarakat, khususnya dalam hal ini dunia usaha/industri (DU/DI).

SDM yang berkualitas sesuai dengan kebutuhan pasar kerja pada DU/DI, maka hubungan antara pihak dunia usaha dan dunia industri dengan lembaga pendidikan maupun nonformal memegang peranan yang sangat penting, seperti merumuskan kebutuhan kualifikasi kompetensi lulusan dari lembaga pendidikan yang diinginkan agar kesinambungan usaha atau industri berjalan dengan baik. Menurut Fransiska (2013), kompetensi kejuruan adalah kesanggupan untuk melakukan tindakan atau kerja, dengan kecakapan dan ketrampilan yang diperoleh melalui pembawaan dan latihan atau praktik tertentu yang dimiliki individu sebagai pencerminan kecerdasan. Pada pendidikan kejuruan penyelenggaraan pendidikan harus sesuai dan sejalan dengan dengan kebutuhan dunia usaha/industri yang mana sejumlah kompetensi atau kemampuan dalam suatu keahlian tertentu yang disyaratkan oleh DU/DI (Depdikbud, 1995).

Menurut KKBI (2021), pengertian alumni adalah orang-orang yang telah mengikuti atau tamat dari suatu sekolah atau perguruan tinggi. Setelah menyelesaikan pendidikannya alumni akan memilih untuk bekerja di dunia pendidikan sesuai displin ilmunya atau di dunia usaha dan industri. Keterserapan alumni dalam dunia kerja selalu dijadikan tolok ukur keberhasilan lembaga pendidikan, tentunya peran lembaga pendidikan memiliki tanggung jawab untuk memfasilitasi serta menjembatani lulusannya untuk memasuki dunia kerja. Untuk dapat mengukur sejauh mana keberhasilan membentuk lulusan-lulusan yang sesuai dengan kebutuhan dan keperluan konsumen (pengguna alumni) perlu diadakan tracer study yang ditujukan kepada stakeholder. Salah satu visi dari Program Studi Pendidikan Teknik Mesin (PTM) Universitas Palangka Raya menghasilkan sumber daya manusia di bidang pendidikan teknik mesin, yaitu menghasilkan tenaga guru SMK. Tetapi sejalan dengan waktu, banyak dari lulusan PTM selain bekerja dalam dunia pendidikan sebagai guru/pendidik, juga berkerja pada dunia usaha/industri. Dari hasil wawancara terhadap 48 alumni Prodi Pendidikan Teknik Mesin, yang berkerja di dunia pendidikan sebanyak 11 orang atau sekitar 21\%, dan sebanyak 37 orang atau 69\% yang bekerja di DU/DI sampai dengan pertengahan tahun 2020. Kurun waktu tahun 2019 sampai dengan tahun 2021 pihak manajemen Pendidikan Teknik Mesin UPR belum memiliki data untuk pengguna lulusannnya dari kalangan DU/DI. Dari besarnya lulusan yang bekerja di DU/DI, maka sangat mutlak hukumnya kompetensi lulusan PTM harus sesuai dengan kebutuhan dari DU/DI sebagai konsumen.

Untuk menjembatani hal tersebut maka sangat perlu diketahui bagaimana kualitas ataupun kemampuan dari lulusan PTM yaitu tujuannya adalah dapat 
menyempurnakan pola penyelenggaraan pendidikannya sehingga menjadi masukan bagi pihak manajemen Program Studi Pendidikan Teknik Mesin. Berdasarkan latar belakang permasalahan yang telah dipaparkan, dapat diidentifikasikan beberapa masalah dalam penelitian ini, yaitu: sampai dengan pertengahan tahun 2020, yang bekerja di DU/DI ada 38 orang atau 69\%, ada 11 orang atau 21\% lulusan PTM yang bekerja di dunia pendidikan, manajemen Program Studi Pendidikan Teknik Mesin UPR pada tahun 2019-2021 belum mengetahui bagaimana penilaian stakeholder mengenai lulusannya. Pengembangan kompetensi dan kemampuan lulusan PTM bersifat mutlak, sehingga menuntut pihak penyelenggara pendidikan PTM UPR berhadapan dengan tantangan pada bagaimana cara membangun pola pendidikan yang lebih baik untuk menghasilkan lulusan yang memiliki kualitas di dunia usaha/industri. Faktor tersebut merupakan salah satu faktor yang penting untuk meningkatkan kualitas daya saing lulusan. Berdasarkan identifikasi dapat dirumuskan permasalahnya didalam penelitian ini, sebagai berikut: (1) Atribut apa saja yang dianggap penting yang harus dimiliki lulusan PTM yang sesuai dengan keinginan stakeholder; (2) Rekomendasi perbaikan seperti apa yang bisa diberikan kepada pihak penyelenggara pendidikan di PTM UPR.

\section{METODOLOGI PENELITIAN}

Penelitian ini termasuk jenis penelitian deskriptif kuantitatif melalui pendekatan survei. Secara umum, pelaksanaan penelitian ini mencakup tiga langkah berikut: 1) pengembangan konsep dan instrumen; 2) pengumpulan data; serta 3) analisis data dan pelaporan. Penelitian ini bertujuan mendeskripsikan penilaian pengguna alumni terhadap kompetensi lulusan Pendidikan Teknik Mesin FKIP UPR.

Menurut Sugiyono (2010), metodologi penelitian merupakan suatu langkahlangkah sistematis yang akan menjadi pedoman dalam menyelesaikan masalah. Dengan adanya metode penelitian, maka penyusunan hasil penelitian akan memiliki alur yang sistematis, ada 4 (Empat) tahapan dalam penelitian ini, yaitu: (1) Identifikasi permasalahan, (2) Mengumpulkan data, berupa keinginan dari konsumen (Stakeholder); (3) Mengurutkan kebutuhan Stakeholder; (4) Tahap akhir yaitu analisa pembahasan, kesimpulan dan saran.

\section{Instrumen Penelitian}

Dalam penelitian ini, instrumen yang digunakan dalam adalah angket (kuesioner), wawancara dan dokumentasi. Adapun jumlah butir pertanyaan yang terdapat dalam angket adalah skala yang digunakan dalam angket penelitian ini adalah jenis skala Likert. Nemoto, et.al. (2014) menyatakan skala Likert adalah skala psikometrik yang memiliki beberapa kategori dari mana responden memilih untuk menunjukkan pendapat mereka, sikap, atau perasaan tentang masalah tertentu. Pada penelitian ini menggunakan skala Likert dengan lima poin (Tabel 
1), digunakan mengukur sikap. Menurut Chyung, et. al. (2017), titik tengah pada penggunaan lima poin skala likert, pada tengah mewakili kenetralan (jangkar). Chyung, et. al. (2017) mengemukakan perbedaan antara skala Likert 4 poin dan Skala Likert 5 poin terletak pada titik tengah. Kehadiran titik tengah membuat perbedaan dalam memperlakukan skala sebagai skala interval hanya jika responden survei menggunakan titik tengah skala Likert untuk pengukuran yang benar. makna netral, sebagaimana dimaksud. Dengan menggunakan skala Likert, maka variabel yang akan dukur dijabarkan dari variabel menjadi dimensi, dari dimensi dijabarkan menjadi indikator, dan dari indikator dijabarkan menjadi subindikator yang dapat diukur.

Tabel 1. Skala Likert

\begin{tabular}{cl}
\hline Nilai & \\
\hline 1 & Sangat Tidak Baik \\
\hline 2 & Tidak Baik \\
\hline 3 & Biasa \\
\hline 4 & Baik \\
\hline 5 & Sangat Baik \\
\hline
\end{tabular}

\section{Kisi - Kisi Instrumen Penelitian}

Kimberlin \& Winterstein (2008) menyatakan memilih instrumen yang ada sebelum mengembangkan tes baru atau ukuran, seorang penyidik harus mengidentifikasi instrumen yang ada yang mengukur konstruk minat. Menggunakan instrumen yang ada yang memiliki bukti substansial keandalan dan validitas dalam berbagai populasi lebih hemat biaya daripada memulai dari awal untuk mengembangkan dan memvalidasi sebuah instrumen. Seperti disebutkan sebelumnya, fokus dari penelitian ini adalah untuk mengidentifikasi dan mengevaluasi persepsi DU/DI terhadap keterampilan kerja lulusan Pendidikan Teknik Mesin. Metode yang digunakan untuk pengumpulan data/sampel dilakukan secara acak. Kisi - kisi instrumen penelitian diambil dengan meninjau studi sebelumnya serta berdasarkan atribut yang dikembangkan oleh Shukri, et.al., (2014), daftar keterampilan kerja lulusan dikembangkan sehingga berfokus pada keterampilan komputasi, keterampilan manajemen, kritis skills keterampilan berpikir, keterampilan perusahaan dan kewirausahaan, keterampilan interpersonal, komunikasi keterampilan dan keterampilan berpikir.

\section{HASIL PENELITIAN DAN PEMBAHASAN Deskripsi Data Penelitian}

Jumlah lulusan Pendidikan Teknik Mesin dari tahun 2019, 2020 dan 2021 sebanyak 110 orang alumni. Tempat lulusan bekerja per-angkatannya bervariasi tempat bekerjanya. Dari hasil wawancara pendahuluan yang dilakukan terhadap 48 alumni Prodi Pendidikan Teknik Mesin. Jumlah lulusan yang berkerja dalam dunia 
pendidikan sebanyak 11 orang atau sekitar $21 \%$, dan sebanyak 37 orang atau $69 \%$ yang bekerja di DU/DI sampai dengan pertengahan tahun 2020.

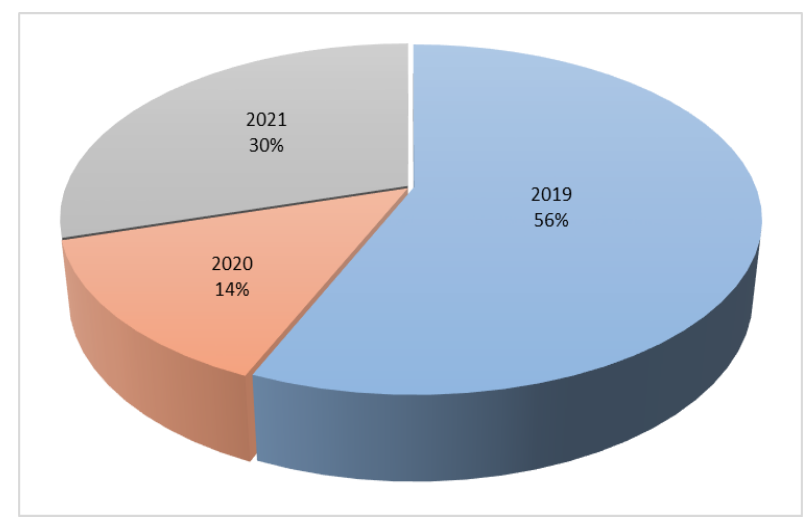

Gambar 1. Rerata Lulusan Tahun 2019 - 2020

\section{Analisa Hasil Penelitian}

Secara praktis penelitian ini diharapkan memberikan pemahaman lebih terhadap apa saja yang menjadi ketercapaian mutu lulusan berdasarkan persepsi dari kalangan DU/DI. Faktor-faktor yang berpengaruh dijadikan salah satu, alternatif atau patokan manajemen dalam pengambilan keputusan. Selanjutnya hasil penelitian ini dapat dijadikan masukan dalam upaya pengembangan mahasiswa dan implementasi pembelajaran yang mempersiapkan lulusan menjadi siap di dunia kerja.

Kesenjangan terbesar dari lima level keahlian adalah keahlian level of keyboard competency dengan jumlah persentase hanya $68 \%$, memiliki nilai gap 32\% atau nilai capaiannya hanya mencapai 17 dari nilai target 25 . Kesenjangan yang terbesar juga terdapat pada Enterprise and entrepreneurial skills, yang hanya mencapai persentase $78 \%$ dan masih ada gap sebesar $22 \%$ atau hanya mencapai nilai capaian 19.5 dari nilai target 25 . Keahlian Interpersonal Skill sampai sejauh ini mencapai nilai target yang tertinggi dari level keahlian lainnya, mencapai nilai 35.5. dari nilai target 40 atau dengan persetase $89 \%$. Yang kemudian disusul oleh level keahlian manajemen skill dan dan komunikasi skill, yaitu masing - masing dengan persentase $87 \%$ dan $83 \%$.

Tabel 1. Nilai Rerata Capaian Per-Variabel

\begin{tabular}{clccc}
\hline No & \multicolumn{1}{c}{ Indikator } & Target & Capaian & Persentase (\%) \\
\hline $\mathbf{1}$ & Interpersonal skills & 40 & 35.5 & $89 \%$ \\
\hline $\mathbf{2}$ & Level of keyboard competency & 25 & 17 & $68 \%$ \\
\hline $\mathbf{4}$ & Communication skills & 60 & 50 & $83 \%$ \\
\hline $\mathbf{5}$ & Management skills & 45 & 39 & $87 \%$ \\
\hline $\mathbf{6}$ & Enterprise and entrepreneurial skills & 25 & 19.5 & $78 \%$ \\
\hline
\end{tabular}




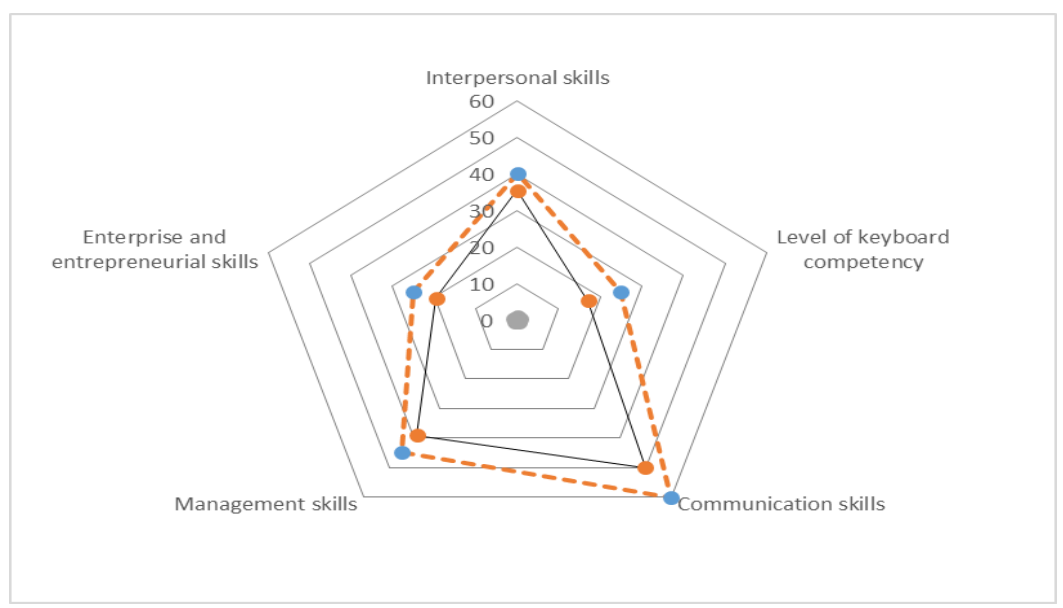

Gambar 2. Diagram Ketercapaian Mutu Lulusan

Ketercapaian variable interpersonal skill hanya $89 \%$ dari nilai target 40 , dengan melihat masih adanya kesenjangan antara $11 \%$ menandakan masih ada yang harus dibenahi dalam perbaikan keahlian interpersonal lulusan. Responden memberikan penilaian yang rendah terhadap bagaimana kemampuan untuk bernegosiasi dengan bawahan atau rekan dan kemampuan untuk bekerja dan memberikan kontribusi kepada kelompok / tim. Untuk penilaian yang tertinggi pada keahlian interpersonal skill adalah kemampuan untuk bekerja dalam lingkungan yang beragam kelompok etnis, agama, dan gender yang disusul dengan kemampuan untuk mendorong dan memotivasi orang lain, kemampuan untuk mengelola orang lain dan kemampuan untuk memahami orang lain masalah, emosi, kekhawatiran, dan perasaan, yang berhubungan dengan pekerjaan. Keahlian ini sangat penting, menurut Berakat (2007), keterampilan interpersonal adalah keterampilan penting bagaimana berhubungan dengan orang lain secara umum dan secara pribadi. Kemampuan untuk menggunakan program database untuk manajemen data memiliki penilaian yang paling rendah dari keahlian Level of keyboard competency, menurut Son, et.al (2011) berdasarkan konsep umum literasi, literasi komputer diartikan sebagai kemampuan menggunakan komputer pada tingkat yang memadai untuk kreasi, komunikasi, dan kolaborasi di masyarakat. Penguasaan teknologi sangat penting, penguasaan penggunaan teknologi dan pengetahuan terkait erat dengan tingkat kepercayaan diri (Atkins \& Vasu, 2000; Lam, 2000; dikutip dalam Son, et al, 2011) dan mempengaruhi sikap mereka terhadap integrasi teknologi (Rakes \& Casey, 2000; dikutip dalam Son, et al, 2011). Kemampuan untuk mengekspresikan ide-ide sendiri jelas, efektif, dan dengan keyakinan merupakan bagian yang diberikan penilaian yang tinggi pada level keterampilan komunikasi. Hal yang mendapatkan penilaian rendah adalah untuk kemampuan untuk bernegosiasi dan mencapai consensus, serta kemampuan 
untuk berkomunikasi secara formal dan informal dengan orang-orang dari latar belakang yang berbeda. Keterampilam komunikasi bagi profesional menurut Mishra, et al (2020) adalah kunci untuk meningkatkan teknis pengetahuan, keterlibatan di tempat kerja secara dinamis tahapan dan menuntut perdamaian, mengubah bisnis skenario dan kesuksesan keseluruhan dalam karir. Komunikasi didefinisikan oleh Edgar Dale (Mishra, et al, 2020) sebagai "berbagi ide dan perasaan dari hati ke hati". Pengetahuan, keterampilan, dan sikap diinginkan untuk komunikasi yang efektif dapat diajarkan dan dipelajari (Cherri et. al., 2002).

Kemampuan untuk mengekspresikan ide-ide sendiri jelas, efektif, dan dengan keyakinan merupakan bagian yang diberikan penilaian yang tinggi pada level keterampilan komunikasi. Hal yang mendapatkan penilaian rendah adalah untuk kemampuan untuk bernegosiasi dan mencapai consensus, serta kemampuan untuk berkomunikasi secara formal dan informal dengan orang-orang dari latar belakang yang berbeda. Keterampilam komunikasi bagi profesional menurut Mishra, et al (2020) adalah kunci untuk meningkatkan teknis pengetahuan, keterlibatan di tempat kerja secara dinamis tahapan dan menuntut perdamaian, mengubah bisnis skenario dan kesuksesan keseluruhan dalam karir. Komunikasi didefinisikan oleh Edgar Dale (Mishra, et al, 2020) sebagai "berbagi ide dan perasaan dari hati ke hati". Cherri, et. al. (2002) menyatakan keterampilan komunikasi tidak hanya verbal, tetapi mencakup spektrum komunikasi nonverbal termasuk bahasa tubuh dan komunikasi tertulis. Lebih lanjut lagi Cherri et. al mengatakan pengetahuan, keterampilan, dan sikap diinginkan untuk komunikasi yang efektif dapat diajarkan dan dipelajari.

Pada level manajemen skill, responden memberikan pandangan akan kemampuan lulusan untuk bekerja secara mandiri sudah cukup baik, kemudian kemampuan untuk memberikan hasil yang diharapkan, merencanakan, mengkoordinasikan, dan mengatur proyek dan kemampuan untuk mengawasi anggota kelompok sudah baik dan memberikan penilaian yang sama. Manajemen skill mutlak harus dikuasai oleh lulusan, menurut De Los Rios, et. al. (2015) manajemen skill dipandang sebagai elemen kunci yang sejajar dengan benchmarking, kedewasaan, sertifikasi, pembelajaran dan pengetahuan. Seperti yang dikutip dalam Hoffman, et.al (2020), keterampilan manajemen adalah salah satu variasi keterampilan "sosial" atau "manusia", keterampilan sosial umumnya dianggap sebagai kemampuan seseorang untuk berkomunikasi secara efektif dengan orang lain (Borghans et al., 2014), dan keterampilan manajemen didefinisikan sebagai kemampuan untuk berinteraksi secara efektif dengan bawahan mereka, sedangkan Deming (2017) keterampilan sosial ditekankan sebagai hal yang penting untuk tim-kerja (produksi horizontal). Menurut Hallinger, et al (2010), Leithwood, et al (2010) seperti yang dikutip dalam Gibbon (2019), kepemimpinan yang baik akan membentuk iklim organisasi dan menciptakan kondisi dan kesempatan belajar menjadi lebih baik. Kemampuan untuk mengembangkan peluang bisnis dan kemampuan untuk memanfaatkan 
peluang bisnis dianggap masih rendah oleh responden. Sedangkan kemampuan untuk mengeksplorasi dan mengidentifikasi peluang bisnis sudah dianggap cukup baik. Keterampilan kewirausahaan dipandang sebagai keterampilan penting yang memungkinkan individu untuk memulai dan mengembangkan bisnis dengan sukses dan menguntungkan (Adeyemo, dikutip dalam Galvao, 2020). Hal ini juga Sejalan dengan yang disampaikan Honig (2004, dikutip dalam Levie, et. al., 2009), kemampuan kewirausahaan bukan karena adanya kesempatan, tetapi juga didapatkan melalui pendidikan dan pelatihan untuk kewirausahaan, hal ini berdampak positif pada aktivitas kewirausahaan dengan meningkatkan keterampilan instrumental yang diperlukan untuk memulai dan mengembangkan. Selanjutnya Liñán (2008, dikutip dalam Galvao, et. al., 2020) mengatakan wirausahawan harus mengembangkan keterampilan seperti kepemimpinan, komunikasi, inovasi, jaringan, kreativitas dan pemecahan masalah karena ini adalah dasar, kapasitas yang diperlukan dari individu yang ingin memulai dan mengembangkan bisnis yang sukses.

\section{KESIMPULAN}

Adapun hasil kesimpulan dari penilitian adalah sebagai berikut : (1) Hasil penelitian didapatkan kesenjangan terbesar dari lima level keahlian adalah keahlian level of keyboard competency dengan jumlah persentase hanya $68 \%$ dengan nilai capaiannya hanya mencapai 17 dari nilai target 25 . Kesenjangan yang kedua didapati pada level enterprise and entrepreneurial skills hanya mencapai persentase $78 \%$ dengan nilai capaiannya hanya 19.5 dari nilai target 25 . Ada tiga keahlian yang mendapatkan persentase nilai yang cukup baik, yaitu keahlian interpersonal Skill mencapai persetase ketercapaianya $89 \%$ atau dengan nilai capaiannya 35.5. dari nilai target 40, pada level ini merupakan yang tertinggi. Level keahlian manajemen skill menempati urutan kedua, dengan persentase $87 \%$ dengan nilai capaiannya 39 dari nilai target sebesar 45, dan komunikasi skill menempati urutan ketiga yang terbaik capaiannya yaitu dengan persentase $83 \%$, memiliki nilai capaian 50 dari nilai target 60; (2) Kelemahan dari lulusan adalah bagaimana mengembangkan dan memanfaatkan setiap peluang yang ada, perlu adanya peningkatan kapasitasnya. Kapasitas seringkali dianggap sebagai kualitas kinerja yang pada dasarnya tidak tergantung pada kemampuan bawaan setiap orang, tetapi itu justru perlu dikembangkan melalui pelatihan, praktek dan pengalaman (Adeyemo, 2009, dikutip dalam Galvao, 2020). Pihak manajemen dan stakeholder perlu mendorong peningkatan kapasitas mahasiswanya sebelum lulus, pengembangan kapasitas mahasiswa bisa dilakukan dengan memberikan kesempatan mahasiswa melalui pelatihan atau kursus pengembangan kepribadian atau pengembangan keahlian lainnya, mengadakan pelatihan/kursus atau memberikan motivasi kepada mahasiswa untuk meningkatkan kapasistas dan kapabilitasnya sebelum menempuh dunia kerja. Hal ini tentunya sejalan dengan dengan program Pemerintah mengenai surat keterangan pendamping ijazah 
(SKPI). Wiyogo, et al (2019), menyampaikan perlu mempertimbangkan prioritas perbaikan dan selalu melakukan evaluasi secara berkala dan konsisten. Pihak pemangku kebijakan (stakeholder) peru mengarahkan dan mendukung pihak manajemen dalam upaya perbaikan yang berkelanjutan.

\section{DAFTAR RUJUKAN}

Chyung, Seung \& Roberts, Katherine \& Swanson, Ieva \& Hankinson, Andrea. (2017). Evidence-Based Survey Design: The Use of a Midpoint on the Likert Scale. Performance Improvement. 56. 15-23. 10.1002/pfi.21727.

Cherri D. Hobgood; Ralph J. Riviello; Nicholas Jouriles; Glen Hamilton (2002). Assessment of Communication and Interpersonal Skills Competencies. , 9(11), 1257-1269. doi:10.1197/aemj.9.11.1257

De Los Rios, Ignacio \& Rodriguez, Fernando \& Pé, Cristina. (2015). Promoting Professional Project Management Skills in Engineering Higher Education: Project-Based Learning (PBL) Strategy*. International Journal of Engineering Education. 31. 1-15.

Fransiska, Maria., Yudana, I Made., Natajaya, Nyoman. (2013). Kontribusi Praktek Kerja Industri, Bimbingan Karir Kejruan, dan Ekspetasi Karir Terhadap Kompetensi Kejuruan (Studi Pada Mahasiswa Jurusan Tata Boga Undhira Bali). e-Journal Program Pascasarjana Universitas Pendidikan Ganesha Program Studi Administrasi Pendidikan (Volume 4 Tahun 2013). Bali.

Galvão, A., Marques, C. and Ferreira, J.J. (2020), "The role of entrepreneurship education and training programmes in advancing entrepreneurial skills and new ventures", European Journal of Training and Development, Vol. 44 No. 6/7, pp. 595-614. https://doi.org/10.1108/EJTD-10-2019-0174

Gibbons, Lynsey Kay; Wilhelm, Anne Garrison; Cobb, Paul. (2019). Coordinating Leadership Supports for Teachers' Instructional Improvement. Journal of School Leadership, 29(3), 248268. doi:10.1177/1052684619836824

Hoffman, Mitchell; Tadelis, Steven (2020). People Management Skills, Employee Attrition, and Manager Rewards: An Empirical Analysis. Journal of Political Economy, (), 711409-.doi:10.1086/711409

Kimberlin, C. L., \& Winterstein, A. G. (2008). Validity And Reliability of Measurement Instruments Used In Research. American Journal of HealthSystem Pharmacy, 65(23), 2276-2284. doi:10.2146/ajhp070364

Levie, Jonathan, Hart, Mark and Anyadike-Danes, Michael (2009). The effect of business or enterprise training on opportunity recognition and entrepreneurial skills of graduates and non-graduates in the UK. IN: Frontiers of Entrepreneurial Research. USA: Babson.

Mishra, Parul \& Mishra, Sunil. (2020). Functional Aspects Of Communication Skills For Professional Empowerment. 07. 2020. 10.333329/joell.7.1.79.

Nemoto, T., \& Beglar, D. (2014). Developing Likert-Scale Questionnaires. In N. 
Sonda \& A. Krause (Eds.), JALT2013 Conference Proceedings. Tokyo: JALT.

Shukri, Mohamad \& Islam, Rafikul \& Manaf, Noor. (2014). Malaysian Graduates' Employability Skills Enhancement: An Application Of The Importance Performance Analysis. J. for Global Business Advancement. 7. 181. 10.1504/JGBA.2014.064078.

Sudiyanto. (2014). Evaluasi Diri Mahasiswa Terhadap Komptensi yang Dimiliki. Jurnal Paedagogia, Vol. 17 No. 1 Tahun 2014. Hal. 40-52. ISSN 1026-4109. http://jurnal.fkip.uns.ac.id/index.php/paedagogia Fakultas Keguruan dan Ilmu Pendidikan Universitas Sebelas Maret. Solo.

Sugiyono. (2010). Statistika Untuk Penelitian. Penerbit Alfabeta. Bandung.

Son, Jeong-Bae and Robb, Thomas and Charismiadji, Indra. (2011). Computer literacy and competency: a survey of Indonesian teachers of English as a foreign language. Computer-Assisted Language Learning Electronic Journal (CALL-EJ), 12 (1). pp. 26-42.

Undang-undang Republik Indonesia Nomor 25 Tahun 2009. Tentang : Pelayanan Publik.

Undang-undang Republik Indonesia Nomor 20 Tahun 2003. Tentang: Sistem Pendidikan Nasional.

Unnesco. (2001). Revised Reccomendation Concerning Technical and Vocational Education and Training. Unesco. Paris.

Wiyogo, W., Duling, J. R., \& Debora, D. (2019, February). Quality Function Deployment Analysis for Improvement of Practicum on Mechanical Engineering Education University of Palangka Raya. In 5th UPI International Conference on Technical and Vocational Education and Training (ICTVET 2018) (pp. 24-28). Atlantis Press. 